\title{
A atuação dos "déspotas do sertão" na implantação da ordem constitucional em Minas Gerais: a lógica do não conhecer subordinação
}

\section{The role of the "despots of the hinterlands" in the implementation of constitutional order in the State of Minas Gerais, Brazil: the logic of not knowing subordination}

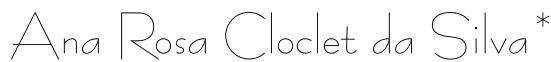

Introdução

No tangenciamento das tensões que permearam a instalação dos instrumentos produtores da unidade orgânica do novo Estado nacional, garantidores de sua soberania e legitimidade, a administração da justiça reveste-se de importância central. Isso porque, dimensão inseparável da expansão do Império português e sua administração, os negócios jurídicos constituíram tradicional locus de mediação entre Estado e Sociedade, dotado de funções não apenas repressoras, mas reguladoras das interações sociais, definidoras, em última instância, dos próprios limites da obediência e da revolta ${ }^{1}$.

Nas Monarquias do Antigo Regime, com sua estrutura jurídico-política corporativa, baseada numa representação das sociedades como politicamente plurais², o "fazer justiça"

\footnotetext{
* Doutora em História pela Unicamp e pós-doutora pela Faculdade de História da USP. Desde 2008, é docente da Faculdade de História da PUC-Campinas, onde desenvolve Projeto de Pesquisa na mesma área. E-mail: cloclet@ig.com.br

${ }^{1}$ MOORE, Barrington Jr. Injustiça: as bases sociais da obediência e da revolta. São Paulo: Brasiliense, 1987, p. 39.

${ }^{2}$ HESPANHA, António Manuel. Poder e Instituições na Europa do Antigo Regime. Lisboa: Fundação Caloutes Gulbenkian, s/d, p. 13.
} 
constituía atribuição do rei por excelência, garantidora do equilíbrio social e da paz sem, contudo, autorizá-lo a intervir diretamente nas instituições encarregadas de executar a "lei", fundada no "costume" e na "tradição" dos autogovernos das corporações. Neste contexto, assume relevo uma concepção da justiça e suas funções como "norma de regulação dos comportamentos sociais", do juizo, como técnica de certificação das hierarquias e "mecanismo de decisão dos litígios", e dos juristas, como construtores e "mediadores das relações sociais". ${ }^{3}$

Mediante a "grande novidade estrutural do final da época moderna" - relacionada, segundo Hespanha, ao "aparecimento dos Estados, o caráter 'macro' do novo modelo de organização política 'estadual' do liberalismo" - a generalização e unificação do direito sob a forma da lei geral ${ }^{4}$ passa a constituir temática crucial, relacionada às possibilidades de gestão territorial do poder "nestes novos espaços alargados" "soberania do povo".

No mundo luso-brasileiro, este fenômeno se manifesta, sobretudo, a partir de meados do XVIII, quando entra em curso uma profunda mudança do imaginário político, no concernente a concepções de sociedade e poder, sob influência do direito natural de base racionalista. Mas é somente com a eclosão revolucionária de 1820 que se processa uma efetiva operacionalização de concepções de sociedade e poder de cunho jusnaturalista ${ }^{6}$, atrelando as definições em torno da Lei e sua aplicação à confecção de um novo "pacto social". Efetivada a ruptura luso-brasileira, seria esta dimensão estruturante do novo Estado nacional, cabendo aos deputados reunidos na Assembleia Constituinte e Legislativa de 1823 consolidarem o

${ }^{3}$ HESPANHA, António Manuel. História de Portugal Moderno. Lisboa: Universidade Aberta, 1995, p. 79.

${ }^{4}$ HESPANHA, António Manuel, “Pequenas Repúblicas, Grandes Estados. Problemas de organização política entre Antigo Regime e Liberalismo". In: JANCSÓ, István (org.). Brasil. Formação do Estado e da Nação. São Paulo: Ed. Unijuí; Fapesp, 2003, p. 93-95.

${ }^{5}$ Sobre este fenômeno que assiste a época moderna, ver: SILVA, Ana Cristina Nogueira da. A constituição espacial do Estado moderno. Lisboa: Estampa, 1998.

${ }^{6}$ HESPANHA, António Manuel e XAVIER, Ângela Barreto, “A representação da sociedade e do Poder", in: MATTOSO, José (dir.). História de Portugal. O Antigo Regime. Rio de Mouro: Lexi Cultural, 2002, p. 145-172. 
A atuação dos "déspotas do sertão" na implantação da ordem constitucional ...

novo ideal de "representação política", alicerçado na concepção de que a "lei" criaria o "Direito" e não o contrário. ${ }^{7}$

Desde então, a reforma do sistema judiciário assumiria o caráter de instrumento privilegiado na garantia da estabilidade da ordem interna e da aplicação da lei, atribuída ao próprio governo, entretecendo-se a outras dimensões caras à nossa experiência constitucional, como era o caso da premente definição dos critérios de cidadania, representatividade política, soberania e da própria definição do nacional, já que também não eram consensuais as posturas nesse sentido.

Tal empenho significava lidar com a necessária composição entre poderes locais e central, público e privado, bem como com um quadro institucional e uma "estrutura da comunicação politica"8 herdados do Antigo Regime, que tornavam a aplicação da justiça profundamente entranhada nas redes hierárquicas e comunitárias, dado representarem os cargos da magistratura meio privilegiado de acesso ao poder, riqueza e distinção, por parte daqueles que os ocupavam. ${ }^{9}$

Atento às implicações de tal quadro para o processo de afirmação de uma esfera pública de poder nas Minas oitocentistas, o presente texto busca mapear a natureza das tensões que envolveram aqueles homens portadores de recursos simbólicos e materiais, os quais, temendo perder suas posições de mando e distinção social, resistiram aos enquadramentos

\footnotetext{
${ }^{7}$ SLEMIAN, Andréa. Sob o Império da Lei. Constituição e unidade nacional na formação do Brasil (1822-1834). São Paulo: HUCITEC, 2009.

${ }^{8}$ HEPANHA, António Manuel, "Pequenas Repúblicas, Grandes Estados”, op. cit., p. 93.

${ }^{9}$ Analisando os critérios de definição do perfil ideal dos bacharéis que ingressavam na burocracia judiciária, Wehling mostra como estes continuaram dependentes de "indicadores estamentais ('nobreza em senso lato', isto é, não exercício de função mecânica'), étnicos ('pureza racial', isto é, não existência de sangue judeu, mouro, mulato ou cigano), religiosos (catolicismo tradicional e não recente), e morais (boa conduta)". (WEHLING, Arno Wehling \& WEHELING, Maria José, "Sociedade Estamental e Estado. As leituras de Bacharéis e o Ingresso à Burocracia Judiciária Portuguesa. O Caso Luso-Brasileiro", in: Revista do Instituto Histórico e Geográfico Brasileiro, 156 (387), abr./jun. de 1995, pp. 253-263). Também em sua análise sobre as instituições do Antigo Regime, Hespanha constata que, no contexto da definição dos requisitos funcionais ao bom desempenho do cargo burocrático, o direito aparecia como uma formação essencial, devido não apenas à falta de "disciplinas técnicas particulares" quanto ao próprio prestígio social adquirido pelos juristas. Daí, portanto, a praticamente indissociável associação do burocrata com o letrado. (HESPANHA, António Manuel. Poder e Instituições na Europa do Antigo Regime. Lisboa: Fundação Calouste Gulbenkian, 1984, p. 77).
} 
institucionais em curso. Para tanto, as reflexões seguintes privilegiam um recorte específico da província de Minas Gerais: a comarca de Paracatu, sertão noroeste mineiro, onde as tensões entre o poder público - em construção - e os diversos níveis do poder privado se mostraram particularmente agravadas na conjuntura do Primeiro Reinado, em virtude da presença de verdadeiros potentados locais, cujas atuações acabaram emperrando o processo de normatização da vida e instabilizando a já precária ordem vigente.

\section{Aplicar a Lei e reformar a justiça}

Na conjuntura do Primeiro Reinado, a organização e a prática jurídica nas Minas Gerais condicionaram-se, em boa medida, pelas determinações da Carta de Lei de 23 de outubro de 1823, que dava nova forma aos governos das províncias, ordenando que os processos do Brasil fossem submetidos às leis portuguesas - até que a legislação pátria viesse substituir a antiga formatação adotada - e consolidando a independência do poder judicial em relação ao ofício de presidente de província. ${ }^{10}$

Por sua vez, o intuito de alçar o Brasil à condição das modernas nações europeias, rompendo definitivamente com o passado colonial, envolveria o esforço de organização de um processo criminal e penal para a jovem nação independente. Para tanto, um longo processo de racionalização, por meio do mapeamento da situação vigente, fora encarregado às diversas cabeças de comarca pelos respectivos presidentes de provincia, redundando em inúmeros requerimentos de informações sobre o estado da instrução pública, elaboração de mapas estatísticos da população, levantamento do número de presos e elaboração de livros de rol de culpados, juntamente com depoimentos sobre o estado da aplicação da justiça, fornecendo os elementos necessários à elaboração do Código Criminal, promulgado em 16 de dezembro de 1830.

\footnotetext{
${ }^{10}$ Segundo a lei em caráter provisório, ao presidente passariam a competir "todos os objetos, que demandem exame e juízo administrativo", estando, porém, independente a administração da Justiça. (Coleção das Leis do Império do Brasil. Rio de Janeiro: Imprensa Nacional, 1887. 2 partes). Tal disposição seria confirmada pela Constituição de 1824.
} 
A atuação dos "déspotas do sertão" na implantação da ordem constitucional ...

Em meio a tal processo, consolidam-se mudanças e explicitam-se as heranças da antiga administração. Daí, na perspectiva dos liberais-moderados mineiros, além das reformas materiais e dos enquadramentos institucionais em curso, impunha-se o urgente aperfeiçoamento do Judiciário, necessidade confirmada por diagnósticos como o emitido pelo desembargador Manuel Inácio de Melo e Souza, que, em 1827, denunciava o "deplorável estado da prolongada prática dos processos forenses e a urgente necessidade de reforma", sendo os cargos da magistratura ocupados por homens "sem probidade, sem exercício do fórum, e sem as mais qualidades necessárias para tratar com o povo em negócios de tanta importância"11. No mesmo ano, Bernardo Pereira de Vasconcelos defendia ser esta "parte da nossa legislação a que reclama mais a atenção da Câmara dos srs. Deputados, e em que se há de fazer muita reforma". ${ }^{12}$

O sentido desta última, registrado nos Relatórios anuais do Ministério da Justiça e nos Debates na Câmara dos Deputados, convergia para a defesa de uma melhor distribuição da Justiça, capaz de agilizar os procedimentos processuais, o que atendia aos interesses daqueles grupos locais, propugnadores da descentralização também na esfera do poder judiciário, cuja fonte residia no Imperador, responsável pela nomeação dos ouvidores e juízes de fora. ${ }^{13}$

Embora tal reforma só viesse a se consumar com a elaboração do Código do Processo Criminal, tornado lei em 15 de outubro de 1832, foi antecedida pela criação do cargo de juiz de paz, pela lei de 15 de outubro de 1827, o qual, segundo Thomas Flory, "sinalizou o começo de uma época de reforma e ascensão

11 “A administração em Minas Gerais, 1827". Memória do Desembargador Manuel Ignácio de Mello e Souza. In: Revista do Arquivo Público Mineiro, ano III, p. 6-22, 1898.

${ }^{12}$ VASCONCELOS, Bernardo Pereira de, "Carta aos senhores eleitores da Província de Minas Gerais". In: CARVALHO, José Murilo de (org.). Bernardo Pereira de Vasconcelos. São Paulo: Ed. 34, 1999, p.111.

${ }^{13}$ Os cargos da ouvidoria e juizado de fora foram criados, respectivamente, nos anos de 1534 e 1696, sendo ambos providos pelo rei, com ampla jurisdição nas capitanias onde atuavam. Após a Independência, permaneceram diretamente atrelados ao Executivo. Sobre estas atribuições, ver: SALGADO, Graça. Fiscais e meirinhos: a administração no Brasil Colonial. 2. ed. Rio de Janeiro: Nova Fronteira, 1985. p. 259-262; e NEQUETE, Lenine. O poder judiciário no Brasil a partir da Independência. Porto Alegre: Livraria Sulina Editora, 1973. 
iminente dos liberais" ${ }^{\prime 4}$, por se tratar de um cargo eletivo para ser exercido em cada freguesia e capela filial, independente do poder centralizador e sem formação profissional específica. Tal qual concebido, destinava-se o juiz de paz a desempenhar as "funções de juiz em assuntos de pouca importância". Ele também "conciliaria os litigantes em perspectiva", tendo sua importância, sob a ótica descentralizadora, não "tanto em seu potencial de melhoramento do sistema legal, senão na sua 'independência" ${ }^{15}$. As expectativas positivas quanto à lei seriam assim registradas por Bernardo Pereira de Vasconcelos:

Os juízes de paz, como bons pais de família, procurarão conciliar as partes que intentarem ir a juízo, e hão de obter muito mais acomodações, de que presentemente conseguem, não tendo os juízes de paz interesse nas demandas que hão de ser tratadas perante outros juizos. Os pleitos insignificantes e os delitos de pequena entidade serão julgados perante estes escolhidos do povo. Sendo um axioma incontestável que antes se previnam do que punam os delitos, é esta uma das mais belas atribuições destas novas autoridades constitucionais. ${ }^{16}$

Entretanto, se os novos juízes converteram-se em "focos locais de apoio político liberal", não foram menos desprezíveis os efeitos ambíguos trazidos pelo próprio intento político em dotá-los de ampla autonomia e poderes que suplantavam os de "qualquer outra instituição judicial ou de outro tipo, em sua jurisdição" ${ }^{17}$. Além disso, a ênfase no atributo da independência do cargo, em detrimento da sua eficácia, ainda que não tenha sido consensual entre os próprios liberais, implicou que, até 1832, inexistissem quaisquer codificações legais sobre suas funções. ${ }^{18}$

${ }^{14}$ FLORY Thomas. El juez de paz el jurado en el Brasil imperial. Control social y estabilidad política en el nuevo Estado. México: Fondo de Cultura Económica, 1986. p. 81 (tradução minha).

${ }^{15}$ Ibidem, p. 84.

${ }^{16}$ VASCONCELOS, Bernardo Pereira de Vasconcelos, “Carta aos senhores eleitores da Província de Minas Gerais", op. cit., p. 112.

${ }^{17}$ Esta última estendia-se às esferas judiciais, administrativas e policiais, incorporando os poderes de três instituições prévias, encarregadas de despacharem os assuntos judiciais menores: o juiz ordinário, o juiz de vintena e o juiz de almotaçaria, então existentes. Cf. FLORY. El juez de paz el jurado en el Brasil imperial, op. cit., p. 85-86.

${ }^{18}$ Com a elaboração do Código do Processo Criminal, a organização judiciária nas Comarcas ficaria assim estruturada: cada comarca contaria com no máximo três juízes de direito, 
A atuação dos "déspotas do sertão" na implantação da ordem constitucional ...

Desse modo, não tardaram a aparecer conflitos entre os juízes eleitos e os magistrados da Coroa - os juizes de fora e os ouvidores - cujo "orgulho corporativo", segundo Flory, via-se "ofendido ao ter que compartilhar uma autoridade mal definida com pessoas não profissionais eleitas pelo povo, e carentes de treinamento" ${ }^{19}$. A falta de competência, por sua vez, era a crítica retribuída pelos juízes de paz aos próprios magistrados diretamente escolhidos pelo imperador, representando um argumento de peso nas disputas pelo poder, já que supostamente isento de rixas pessoais e assentado num qualificativo que os diferenciava daqueles magistrados: o fato de serem conhecedores da vida local e, por isso, estarem aptos a interferir em conflitos de natureza até mesmo pessoal, que muitas vezes instabilizavam a administração pública. ${ }^{20}$

As tensões refletiram-se, ainda, no relacionamento desses representantes do judiciário com o poder provincial, pois eram frequentes as queixas do Conselho acerca da negligência dos juízes de paz em providenciarem as informações e estatísticas solicitadas, das quais dependia um mais preciso reconhecimento do espaço público sob sua jurisdição ${ }^{21}$. Mais gritante, porém, foram as queixas acerca dos abusos de jurisdição dos encarregados de executar a lei envolvendo, aqui, tanto os magistrados da Coroa quanto os juízes de paz e ordinários, esses últimos exercendo concomitantemente funções administrativas e judiciárias em nível local. ${ }^{22}$

nomeados pelo imperador, e um chefe de polícia, o qual era escolhido entre os juízes, nas cidades mais populosas; em cada termo, haveria o Conselho dos Jurados (escolhido por alistamento), o juiz municipal e o promotor público (nomeados pela Corte e presidentes de província), o escrivão de execuções e os oficiais de Justiça; em nível dos Distritos, haveria o juiz de paz (eleito), o escrivão, os inspetores de quarteirão e os oficiais de Justiça (nomeados pelas câmaras). Código do Processo Criminal do Império do Brasil, apud VELLASCO, Ivan de Andrade. As Seduções da Ordem. Violência, Criminalidade e administração da justiça. Minas Gerais, século 19. Bauru: Edusc, 2004, p. 122.

${ }^{19}$ FLORY, Thomas. El juez de paz el jurado en el Brasil imperial, op. cit., p. 85.

${ }^{20}$ Arquivo Público Mineiro, Fundo: Presidência de Província (PP 2/1)- Documentação expedida/Governo Imperial, Ministérios e Assembleia Geral, cx. 2, 18 de agosto de 1828 (grifo meu).

${ }^{21}$ FLORY, Thomaz, op. cit., p. 106

${ }^{22}$ LEMOS, Carmem Silvia. A Justiça local: os juízes ordinários e as devassas da Comarca de Vila Rica (1750-1808). UFMG, 2003 (Dissertação de mestrado). p. 14. 
Na verdade, o que se observa durante todo o Primeiro Reinado - não desaparecendo nem mesmo depois da Abdicação - é uma grande confusão legal e a ausência de formulações específicas, agravada pelo desconhecimento das que existissem para cada um desses cargos. Além disso, embora a ouvidoria e o juizado de fora tenham sido frequentemente associados ao intuito centralizador do Executivo, remetendo ao antigo despotismo, não fugiram ao estigma mais comumente aplicado aos juizes sem preparo profissional: o desenvolvimento de laços com suas respectivas localidades, redundando em favoritismos nas disputas por eles arbitradas, na interpenetração de relações pessoais nos negócios burocráticos, minando as possibilidades de uma administração racional. Tudo isso, dificultando a previsibilidade da ordem e, seguramente, anulando boa parte daqueles esperados "resultados positivos para o andamento da justiça e seus beneficiários". ${ }^{23}$

Em suma, podemos dizer que a conjuntura do Primeiro Reinado notabiliza-se pelos esforços de internalização do domínio das decisões e leis, guiados pelas preocupações de disciplinarização do povo e da implantação do sistema constitucional, articulado à constituição de um conjunto orgânico e homogêneo. Na prática, contudo, permaneceram os conflitos que instabilizaram a ordem e a aplicação da justiça, gerando tensão no relacionamento entre as esferas do poder local - as câmaras - e a administração judicial da província, atribuída aos juízes de paz, em nivel dos distritos, aos juízes de fora, nos termos das vilas, e aos ouvidores, com atuação em toda a comarca.

No caso mineiro, o quadro descrito mostrava-se particularmente agravado naquelas Vilas mais distantes, quer da capital, quer do circuito Rio-Minas. Aí, além das tensões entre o corpo de ministros encarregados de aplicar a lei, o contexto inicial de implantação da ordem constitucional foi marcado pela atuação daqueles protagonistas que, portadores de grande poder e autonomia, informavam o quadro descrito por José de Sá Bettencourt Acióli, em 1799:

[...] quase todo o sertão que fica nas extremidades das capitanias da Bahia, Minas Gerais, Goiases e Pernambuco sofre grandes incômodos pela falta da administração da Justiça, por causa

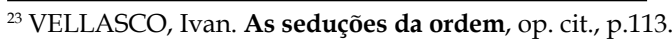


A atuação dos "déspotas do sertão" na implantação da ordem constitucional ...

dos longos caminhos e pela mesma razão: o respeito da régia autoridade nestes lugares é bem à semelhança da luz, cujos raios são tanto mais fracos quanto maior é a sua distância do foco. ${ }^{24}$

Assim, nestes territórios distantes dos centros de decisão politica, os chefes locais, amparados por seus representantes imediatos - geralmente parentes e agregados - acabaram não só interferindo nos negócios da justiça como representando "outra legislação"25. É este o perfil dos acontecimentos ocorridos na Vila de Paracatu do Príncipe, paradigmáticos na denúncia do peso assumido pelos potentados locais na implantação da nova ordem constitucional.

\section{Potentados do sertão paracatuense: a lógica do "não conhecer subordinação"}

Situada no longínquo noroeste mineiro, divisando com o sertão baiano e com a província de Goiás, a região de Paracatu teve sua ocupação proveniente da Bahia, via São Romão ${ }^{26}$, tendo como atividade inicial a pecuária, passando, a partir de 1744, à exploração aurífera. Sua elevação a Vila só ocorreu em 1798 (embora pleiteasse este status desde 1745), sendo, por alvará de 17 de maio de 1815, criada a Comarca de Paracatu, desmembrada da Comarca de Sabará, "pela grande distância em que ficam aquelas povoações da dita Vila; pela dificuldade que oferece a passagem do Rio S. Francisco e por suceder não se poder fazer por muito tempo as correições que os Ouvidores Gerais, na conformidade das leis, devem fazer anualmente em todas as terras da sua Comarca". ${ }^{27}$

\footnotetext{
${ }^{24}$ Apud, Emanuel Araújo, “Tão vasto, tão ermo, tão grande: o sertão e o sertanejo nos tempos coloniais". In: DEL PRIORE, Mary (org.). Revisão do Paraíso. Rio de Janeiro: Campus, 2000, p. 78.

${ }^{25}$ SILVEIRA, Marco Antônio, op. cit., p. 167.

${ }^{26}$ Segundo Oliveira Mello, as duas primeiras bandeiras que aí fizeram arranchamento foram a de Felisberto Caldeira Brant - mineiro de São João Del Rei, provindo das minas de Goiás - e a do paulista José Rodrigues Fróis - proveniente da Bahia, de modo que Paracatu surgia no limite das penetrações vindas de São Paulo e do Nordeste. (MELLO, Oliveira. As Minas Reveladas (Paracatu no Tempo). 2. ed., Paracatu: Prefeitura Municipal, 2002. p. 78).

${ }^{27}$ CARVALHO, Theophilo Feu de. Comarcas e Termos. Criações, supressões, restaurações, incorporações e desmembramentos de comarcas e termos, em Minas Gerais (1709-1915). Belo Horizonte: Imprensa Oficial do Estado de Minas Gerais, 1922. p. 42.
} 
Embora possa ser descrita como "um caso peculiar na história do sertão", pelo fato de a mineração ter aí gerado, desde o século XVIII, uma "organização política e econômica semelhante àquela que se desenvolveu no centro de Minas" - com a presença da máquina burocrática metropolitana ${ }^{28}$ e da escravidão negra ${ }^{29}$ - a história política de Paracatu se revela profundamente marcada pelo perfil de uma sociedade agropastoril, onde imperava o poder de potentados locais no jogo político local e regional.

A situação era agravada pelo fato de, geralmente, tratarem-se de homens detentores de verdadeiros exércitos privados, organizados em torno do "chefe local" mediante vínculos fundados em variáveis de forte poder coesivo - como a lealdade, a gratidão, o compadrio, as dividas financeiras e as experiências de luta contra inimigos comuns -, contrastando com a frágil organicidade esgarçada pelo corpo de oficiais encarregados de aplicar a lei.

A condição de patronos de bandos armados - bem como o fato de serem eles próprios freqüentemente imbuídos de patentes - revela-se tributária do peculiar processo de ocupação do território colonial, especialmente nas suas partes mais remotas onde, não dispondo a Coroa "de meios e condições para controlar e defender o território, delegara essas funções àqueles aos quais outorgava terras de sesmaria". Desse modo, "eram os próprios sesmeiros" que representavam o Estado, "com patentes militares e mantendo à própria custa as tropas de mamelucos e indios aculturados". ${ }^{30}$

\footnotetext{
${ }^{28}$ Renato Venâncio destaca como traço atípico do lugar, indicando sua posição de posto avançado do império colonial português, a forte presença de homens provindos da metrópole, atraídos pelo ouro. (VENÂNCIO, Renato Pinto, "Comércio e Fronteira em Minas Gerais Colonial", in: Júnia F. Furtado (org.), Diálogos Oceânicos. Minas Gerais e as novas abordagens para uma História do Império Ultramarino Português. Belo Horizonte: Editora da UFMG, 2001. p. 90).

${ }^{29}$ MATA-MACHADO, Bernardo. História do Sertão Noroeste de Minas Gerais (16901930). Belo Horizonte: Imprensa Oficial, 1991. p. 50.

${ }^{30} \mathrm{O}$ próprio regimento dado a Tomé de Souza em 1548 já os obrigara a construir torres ou casa fortes, como Garcia D'Ávila o fizera em Tatuapara. (BANDEIRA, Luiz Alberto Moniz. O Feudo. Rio de Janeiro, Civilização Brasileira, 2000).
} 
A atuação dos "déspotas do sertão" na implantação da ordem constitucional ...

Conforme Prado Jr. ${ }^{31}$, a estrutura militar na época colonial estava ancorada em dois niveis de forças repressivas: a tropa regular, ou de primeira linha - composta por oficiais pagos e, normalmente, portugueses - e as auxiliares - as milícias e corpos de ordenanças, formadas por gente recrutada nas freguesias, sem remuneração e sob o comando de grandes proprietários, ou militares possuidores de patentes. É por intermédio deste corpo que a Coroa, destituída de recursos para ampliar as tropas de linha, exercerá seu esforço para afirmar-se e preservar a ordem interna, implicando que as milícias tenham adquirido grandes proporções, como no caso das zonas mineradoras ${ }^{32}$. Por fim, existiam as ordenanças, formadas por população masculina entre 18 e 60 anos, não incorporada na tropa de linha e nas milícias, constituindo força local, com atuação limitada à área de residência de seus efetivos e acionada apenas nos momentos de risco iminente. Uma situação que propiciava a manipulação dos terços de ordenanças pelos proprietários rurais, colocando-os a serviço de causas particulares. ${ }^{33}$

As interpretações acerca do significado do poder exercido por estes potentados do sertão variam desde aquelas que os entendem como "desligados dos interesses metropolitanos" - e, portanto, como pouco propícios à ação fiscalizadora da Coroa, fazendo da região do vale um "reduto de ordem privada" e "soberania fragmentada" - até aquelas que, embora aceitando que no Vale do São Francisco desenvolveu-se uma "economia dinamizada", em grande medida desvinculada dos "canais habituais

\footnotetext{
${ }^{31}$ PRADO JR., Caio. Formação do Brasil Contemporâneo. 9. ed., São Paulo: Brasiliense, 1969. p. 310.

${ }^{32}$ Especificamente sobre a organização militar em Minas Gerais, no século XVIII, ver o recente estudo de COTTA, Francis Albert, No Rastro dos Dragões: políticas de ordem e o universo militar nas Minas setecentistas, Belo Horizonte: UFMG, FFCHU, 2004. (Tese de doutoramento).

${ }^{33}$ Segundo comentário do ouvidor de Jacobina, José da Silva Magalhães, registrado em correspondência enviada ao príncipe solicitando um destacamento de Dragões para "tranquilizar os povos" daquele distrito, os membros das ordenaças eram "protetores dos malfeitores para os terem prontos para suas prepotências". (ARQUIVO PÚBLICO MINEIRO, Seção Colônia, Secretaria de Governo, cx 53, doc 39, 1801; apud, ANASTÁSIA, Carla. Vassalos Rebeldes. Violência coletiva nas Minas na segunda metade do século XVIII. Belo Horizonte: Ed. C/Arte, 1998. p. 74.).
} 
da comercialização" ${ }^{34}$, entendem o poder dos potentados como representando e materializando os próprios interesses metropolitanos no sertão.

Neste último sentido, afirma-se, a Coroa "não tendo condições de se fazer presente no sertão, incentivou e delegou poderes à ordem privada de conquista e domínio do espaço geográfico e humano", fazendo do potentado o "detentor de um poder autônomo e não soberano ${ }^{35}$. Analisando os condicionantes da investidura militar destes potentados, por sua vez, Moniz Bandeira afirma serem os sesmeiros daquela região - os "senhores da Torre" - representantes do Estado, portadores de patentes militares e mantendo à própria custa as tropas de mamelucos e índios aculturados ${ }^{36}$. Deles o próprio governo-geral do Brasil sempre dependera, pois, desde o início da colonização, a Coroa não dispunha de meios e condições para controlar e defender o território, delegando essas funções, geralmente, àqueles aos quais outorgava terras de sesmaria.

Em qualquer dos casos, porém, é inegável o peso desta esfera de poder privado como elemento de coesão societária na região em foco, de modo que os senhores de terra, providos dos postos militares mais altos da hierarquia de comando, passaram a representar, com seus terços, os índios, mamelucos

\footnotetext{
${ }^{34}$ Segundo Anastásia: “O sertão agro-pastoril do São Francisco, embora tenha tido seus núcleos formados e dinamizados por conquistadores integrantes de uma empresa promovida pela iniciativa oficial, inseridos em um plano específico de colonização, desvinculou-se do poder público tão logo apoiou-se em uma economia desligada dos canais habituais da comercialização ditada pelas exigências do capital mercantil. Livre, nesta medida, das malhas administrativas, responsáveis pela implantação das formas autoritárias de dominação externa, a área do sertão do São Francisco tornou-se reduto de poder das forças locais que haviam sido combatidas nas regiões dinâmicas da capitania de Minas Gerais". (ANASTÁSIA, op. cit., p. 82-90.)

${ }^{35}$ Neste último sentido, ressalta-se o fato de que tanto a "entrada dos colonizadores no vale foi administrada e controlada, obedecendo a um plano específico de colonização da metrópole, que impedia toda iniciativa individual", quanto a economia de abastecimento interno aí desenvolvida, embora permitisse aos fazendeiros se capitalizarem através do comércio interno e regional, executou-se "sob a supervisão direta do poder metropolitano, que, inclusive, reconhecia a posse da terra ocupada". (SOUZA, Marcos Spagnuolo de. A Ocupação do Vale do Rio São Francisco: Século XVII e XVIII, Goiânia: Universidade Federal, 2002. p. 75).

${ }^{36} \mathrm{O}$ próprio regimento dado a Tomé de Souza em 1548 já os obrigara a construir torres ou casa fortes, como Garcia D'Ávila o fizera em Tatuapara. (BANDEIRA, op. cit.).
} 
A atuação dos "déspotas do sertão" na implantação da ordem constitucional ...

e escravos negros que se uniam nas jornadas. Segundo Diogo Vasconcellos:

[...] o potentado era aquele que defendia o seu povo contra todos aqueles que não estavam sob sua proteção, socorria os governantes com o seu próprio corpo de armas. Em suas fazendas, cultivavam toda espécie de cereais e criavam gado. Possuiam nas fazendas oficinas mecânicas e tecelagens. As fazendas eram de fato vilas e uma numerosa clientela os bajulava e lhes fazia a corte. Nas capelas da fazenda o culto exorbitava de esplendor. Padres e frades revezavam-se pregando a obediência, santificando os senhores e ferindo a imaginação da plebe com festas deslumbrantes. ${ }^{37}$

No caso paracatuense, a atuação destes latifundiários que dominavam as terras no vale do Rio São Francisco, entre o Carinhanha e Paracatu - mistura de fazendeiros, comerciantes e representantes da política metropolitana - condicionou as transformações operadas no quadro econômico e político local após a crise mineradora, quando então, segundo impressões registradas pelo Ouvidor da Comarca, Antônio Paulino Limpo de Abreu, em 1825:

[...] começou com mais fervor a criação de Gados, e plantação de canas, em que hoje consiste a principal riqueza do País, e que são os penhores de sua futura prosperidades, tendo os primeiros gêneros e a sola, e os couros que se fabricam, fácil exportação por terra para varias Provincias do Império, e sendo a aguardente e o açúcar, que se extraem das canas navegados sem embaraço pelo rios Paracatu e S. Francisco abaixo. ${ }^{38}$

Tradicionalmente influentes no jogo político local e regional, estes "poderosos do sertão" paracatuense interferiram no processo da independência e construção inicial do Estado e da Nação brasileiros, buscando preservar e mesmo galgar condições de poder. É esse o perfil dos acontecimentos ocorridos na Vila de Paracatu do Príncipe, no momento da adesão ao constitucionalismo, quando se externaram as disputas entre o Vigário Forâneo Joaquim de Mello Franco - que deixava o cargo de Ouvidor da Comarca, ocupado desde a saída de Gregório de

${ }^{37}$ VASCONCELOS, Diogo. História Antiga de Minas Gerais. 4. ed. Belo Horizonte: Itatiaia, 1999.

${ }^{38}$ Arquivo Publico Mineiro, Fundo: Presidência de Província, (PP 1 / 18), cx 328, Doc. 20. 
Moraes Navarro, em 1812 - e o recém-empossado coronel Antonio Baptista da Costa Pinto, que teria de vencer uma série de dificuldades políticas, dada a grande influência de seu predecessor na localidade ${ }^{39}$. Desse modo, recusando-se a armar de Cavalleiro o sobrinho do Vigário, Francisco Antonio de Assis, este último sublevou o povo contra o Ouvidor em exercício, pretendendo depô-lo e proclamar um governo provisório autônomo.

$\mathrm{O}$ fato foi relatado em correspondência do Ouvidor da Comarca - então refugiado em sua fazenda - ao Governo Provisório instalado em Vila Rica, na qual denunciava as "circunstâncias atuais" presentes na Vila de Paracatu, em que se achava "inquietado o público e impossibilitados os Magistrados de fazerem Justiça livremente, tudo ocasionado por um homem revoltoso, que se tem levantado em Déspota, e pretende ser o árbitro dos destinos de todos", não reconhecendo "Superior, julgando que tudo lhe é permitido". ${ }^{40}$

Segundo o denunciante, o autoritarismo de Antonio de Assis teria se manifestado já na ocasião da eleição do Governo Provisório mineiro, quando procurou, "com todo o empenho logo que chegaram aqui os Eleitores Paroquiais, inquietar os seus espíritos e movê-los a que se unissem para se Criar nesta Vila um Governo Provisório, no projeto de ser ele o Presidente, e com as suas seduções e convites particulares que fazia a alguns Oficiais de Milícias, ia causando uma grande revolução que felizmente se atalhou pela falta de união". Entretanto, segue o documento, mesmo depois de instalado o Governo Provisional e a notícia chegada à Vila de Paracatu, "ainda então aquele homem inquieto se atrevia a convidar os Eleitores, o Tenente José Luiz da Costa Araújo Arios [...] e aos Alferes José Carneiro, José Lopes, o Padre Miguel de Mello Chaves e o Capitão João Pereira da Costa [...] para nova Revolução, e Criação de novo Governo independente do legitimo[...]". ${ }^{41}$

Descrito nestes termos, o movimento ocorrido em Paracatu sugere o peso das disputas patrocinadas pelos potentados locais no jogo político da independência, dimensão ainda pouco

${ }^{39}$ GONZAGA, Olympio. Memória Histórica de Paracatu. Uberaba: 1910, p. 26.

40 "Movimento político em Paracatú (1822)", Revista do Arquivo Público Mineiro, \{s.c.\}, 1898, vol. III, p. 288-290.

${ }^{41}$ Idem. 
A atuação dos "déspotas do sertão" na implantação da ordem constitucional ...

explorada pela historiografia. Uma situação semelhante àquela verificada em algumas Vilas do Alto Sertão baiano, onde também se fez sentir a influência de potentados locais, instaurando uma fragmentação de poderes no contexto da Independência: o Conselho Interino, instalado em Cachoeira, um Governo Provisório, na Vila de Rio das Contas, e fortes dissensões político-militares envolvendo autoridades da Vila de Caetité. ${ }^{42}$.

Tal região, além de ter contado com um processo de ocupação similar ao do Vale do São Francisco e noroeste mineiro, embora anterior ${ }^{43}$ - convergindo a pecuária, com a preação de índios e a busca de minas auríferas, não podendo a Coroa prescindir do poder das armas dos "senhores da terra" ${ }^{44}$-, consolidou-se como a "principal via de comunicação para o São Francisco e uma rota quase obrigatória para os que desejassem chegar às Minas Gerais e a Goiás" ${ }^{45}$. Desenvolveu-se assim, em inícios do XIX, um intenso comércio interno e interprovincial, baseado na produção local de algodão e outros víveres. Neste sentido, não é demais lembrar a passagem em que Saint-Hilaire menciona ter notado, durante sua estada em Paracatu, a presença de "mercadores de Caitité, que procuravam reunir víveres para levá-los para o seu país". ${ }^{46}$

A nosso ver, as vias abertas pelo comércio propiciaram não apenas um perfil peculiar às suas elites - ligadas também por laços de parentesco - mas, o intercâmbio de homens e ideias, informando projetos políticos e vínculos identitários de

${ }^{42} \mathrm{O}$ tema é analisado em recente estudo, sobre o processo de independência no Alto Serão Bahiano, especificamente, nesta última Vila e na de Caetité, pertencente à Comarca de Jacobina. (SOUZA FILHO, Argemiro Ribeiro de, SOUZA FILHO, Argemiro Ribeiro de, A Guerra de Independência na Bahia: Manifestações políticas e violência na formação do Estado Nacional (Rio de Contas e Caetmté). UFBA, 2003 (Dissertação de Mestrado). Sobre o processo de ocupação do Alto Sertão Bahiano, ver: NEVES, Erivaldo Fagundes. Uma Comunidade Sertaneja: da sesmaria ao latifúndio (Um Estudo de História Regional e Local). Salvador: Ed. UFBA, 1998. Ainda sobre o sertão baiano, vale recorrer ao estudo de SOUSA, Maria Aparecida Silva de. A conquista do Sertão da Ressaca: povoamento e posse da terra no interior da Bahia. Vitória da Conquista: 2001.

${ }^{43}$ A ocupação do alto sertão baiano se inicia por volta dos séculos XVII e XVIII, e a criação das referidas Vilas, respectivamente nos anos de 1726 e 1810, embora com autorização por Provisão Régia desde 1803. (idem, p. 72).

${ }^{44}$ Idem, p. 65-67.

${ }^{45}$ Ibidem, p. 70.

${ }^{46}$ SAINT-HILAIRE, Auguste. Viagem às nascentes do Rio São Francisco. Belo Horizonte/ São Paulo: Itatiaia/Edusp, 1975. 
tipo regional, distendendo os contornos de uma espacialidade tipicamente mineira e fragilizando a firmação de uma esfera regional de poder.

Embora a violência e os desmandos fizessem parte do cotidiano de todos os segmentos da sociedade daqueles sertões e proliferassem também nos núcleos urbanos mais adensados ${ }^{47}$, no periodo por nós analisado as resistências dos potentados locais no sentido de preservar ou mesmo galgar aqueles atributos garantidores de distinção, riqueza e poder - tais como terras, escravos e patentes - converteram-se em novos elementos responsáveis pelos conflitos retratados em diversas correspondências emitidas por magistrados e juízes sediados nas regiões mais distantes do poder provincial.

Frequentemente, a atuação destes últimos revela as oportunidades criadas pelas suas peculiares condições de mando e relativa autonomia frente às autoridades publicamente constituídas, no sentido de viabilização da vingança, demonstrando ser este um padrão de conduta compartilhado num universo muito mais abrangente que o urbano, capaz de denotar grandeza e distinção ${ }^{48}$, constituindo importante patrimônio simbólico daquela sociedade.

Assim, em correspondência à Presidência da Província, datada de 5 de outubro de 1825, o Ouvidor Antonio Paulino Limpo de Abreu denunciava a situação vigente no Julgado do Araxá, onde estaria:

[...] abatida, e aniquilada a Justiça, extinta a força moral das autoridades constituídas, conculcadas as Leis, e perturbado ou antes subvertido o sossego público, e a segurança individual por dois homens facciosos e temerários, como são o intitulado Sargento-Mor Antônio da Costa Pereira, e seu irmão Capitão João da Costa Pereira, os quais acoroçoados pela incapacidade e frouxidão dos Juízes territoriais, e por um bando de celerados,

\footnotetext{
${ }^{47}$ No decorrer do século XVIII, estes conflitos envolvendo a atuação de potentados locais e seus bandos armados foram mais frequentes nos sertões do Rio das Mortes e do São Francisco. Contudo, como nota Anastásia, mas não deixaram de instabilizar a ordem também na comarca do Rio das Velhas, mais próxima da ouvidoria sediada em Sabará. (ANASTÁSIA, op. cit., p. 74).

${ }^{48}$ Marco Antonio Silveira enfatiza este código de conduta como proliferando "notadamente no universo urbano". Nossa pesquisa, contudo, demonstra que esta é uma racionalidade passível de ser estendida às áreas do sertão, ainda que aí os dispositivos dos quais podiam valer-se os agentes coevos variassem. (SILVEIRA, op. cit., p. 148).
} 
A atuação dos "déspotas do sertão" na implantação da ordem constitucional ...

que os rodeia, entre os quais é voz pública compreenderem-se vários Desertores acoitados com a mais nefanda protetoria na Fazenda deste último, que é comandante de um dos Distritos do Termo, tem cometido ousada, e impunemente uma série de delitos, ora despersuadindo os Povos de pagar os direitos Nacionais [...] ora desafiando, e espancando as vítimas do seu ódio, e baixa vingança, ora enfim ameaçando com a morte as mesmas Autoridades constituídas se intentassem proceder criminalmente pelos atentados que de dia, e de noite se tem repetido naquele Arraial [...]. ${ }^{49}$

Não raras vezes, a atuação destes fazendeiros guiou-se pelo intuito de proteger seus patrimônios de possiveis perdas materiais causadas pela execução da justiça. Tais investidas eram particularmente comuns quando se tratava de impor limites à condenação de escravos envolvidos em delitos de distintas naturezas. Aqui, as estratégias dos proprietários iam tanto no sentido de intercederem por eles na justiça, solicitando a comutação de penas e procurando evitar suas prisões ${ }^{50}$, quanto no de infringirem a lei, patrocinando as fugas de seus cativos de cadeias ou mesmo antes de serem presos, reincorporando-os às suas propriedades ou vendendo-os a terceiros. Frequentemente, acobertavam em suas propriedades escravos e aliados políticos que cometiam os delitos a mando de seus próprios senhores. ${ }^{51}$

\footnotetext{
${ }^{49}$ Arquivo Público Mineiro, Fundo Presidência de Província (PP 1 / 18), cx 328, doc. 15.

${ }^{50}$ Procedimento que parece ter sido mais usual nas áreas urbanas dos antigos centros mineradores, onde a presença do Estado se impôs de forma mais incisiva, implicando maior dependência da população perante o aparelho administrativo e judicial. (CARDOSO, Maria Tereza Pereira Cardoso, Lei branca e justiça negra: crimes de escravos na comarca do Rio das Mortes (Vilas Del-Rei, 1814-1852). Campinas: Unicamp, 2002. p. 196. (dissertação de mestrado)).

${ }^{51}$ Mesmo naquelas áreas mais próximas ao poder provincial, contudo, e onde a concentração da população escrava era significativamente maior, adensando os riscos de uma sublevação e as ocorrências de crimes contra os próprios senhores, tais estratégias por parte destes, visando proteger suas propriedades, não estiveram ausentes. É este o caso de José Rebollo, escravo de João Machado Neto, acusado de assassinato de um escravo do irmão de seu dono, Felipe Machado Neto, por questões de "envolvimento afetivo do primeiro com a escrava Luzia Banguela (casada com o segundo) que também saiu vitimada nesta oportunidade". Julgado, foi condenado e teve seu nome lançado no livro de Rol de Culpados. Contudo, "a apreensão do responsável pelos delitos não se efetiva", tendo diversas testemunhas inquiridas declarado "que o senhor do delinqüente vendera aquele escravo para a banda de Paraíba". (Arquivo Municipal e Regional de São João Del Rei (MRSJDR), ano de 1831, Cx. PC 01-06).
} 
É esse o teor da Representação enviada pela Câmara de Paracatu ao Conselho Geral da Provincia, em 15 de Outubro de 1831, na qual era denunciado o geral "desleixo das Autoridades Civis e Criminais [que] muito tem concorrido para os frequentes arrombamentos da Cadeia, e fugida de presos, de maneira que tanto que a ela são recolhidos presos de crimes graves, e protegidos, nada mais há a esperar do que a escápula destes, e o prejuízo do Conselho ocasionado pelos ditos arrombamentos". A Representação era movida pelo episódio mais recente, ocorrido com "Maria Nunes Crioula [...] presa por crimes de morte", que teria arrombado e queimado a cadeia, com ajuda de "seus Protetores", para os quais, recomendava, "se devia mandar avaliar o Conserto do estrago, e ruína ocasionada"52. Recomendação reveladora da conivência das próprias autoridades civis com tal situação, pois além de saberem o paradeiro da ré - "havendo presunções e indícios veementes da tentativa de evadir-se da prisão" - não tomavam "as necessárias cautelas pondo-se Guardas e havendo vigilância, como era de costume, quando tal receava, mas antes como que se fecham os olhos", conforme denunciavam os camaristas locais..$^{53}$

Um descaso que, a nosso ver, explica-se tanto pelos possiveis riscos que corriam aquelas autoridades encarregadas de executar a lei - intimidadas pelos potentados e seus bandos -, quanto pelo reconhecimento da fragilidade de suas condições enquanto instâncias pretensamente mantenedoras do equilibrio social, num contexto em que o próprio povo acostumara-se a recorrer a estes poderosos locais, "e não aos ramos do Governo de Sua Alteza Real, antes com ofensa de sua justiça". ${ }^{4}$

Os atos violentos e lesivos à autoridade pública que grassavam naqueles sertões eram ainda adensados pelo fato de serem reduto do mandonismo de "bandoleiros", segmento social que compartilhava dos mesmos códigos de conduta dos chefes

\footnotetext{
${ }^{52}$ Arquivo Público Mineiro, Conselho Geral de Província (CGP 1 / 2), cx , doc. 31.

${ }^{53}$ Idem.

${ }^{54}$ Ambas as dimensões da fragilidade da lei eram apontadas nas memórias do sargento de milícias, Romão Fagundes do Amaral, na qual descrevia o comportamento dos moradores dos sertões do Rio das Mortes. (Memória que oferece o sargento de milícias Romão Fagundes do Amaral ao Ilmo. E Exmo. Sr. Para a clareza, e inteligência, da parte que faz do Serviço de Sua Alteza Real em alguns pontos, de 28 de julho de 1802. (Arquivo Público Mineiro, Seção Colonia, Secretaria de Governo, cx 58, doc 40)).
} 
A atuação dos "déspotas do sertão" na implantação da ordem constitucional ...

locais: "ambos usavam o poder por meio da intimidação física, ambos tinham um séquito leal ao líder e ambos desafiavam a frágil autoridade institucional"55. Segundo Anastásia, em razão da falta de autoridade ou da existência de conflitos de jurisdição - que acabava gerando um contexto de "autoridade fragmentada" - "o direito à violência era alimentado pela noção anárquica de que o banditismo era mais legitimo do que a autoridade ausente ou litigante". ${ }^{56}$

É nesse sentido que sobressai a denúncia de Antônio José da Silva, juiz de paz de Uberaba, distrito da comarca paracatuense, contra a atuação Jerônimo de Sá Cunha, acusado de perpetrar "o roubo de escravos e gado" e que, surpreendido pelo oficial enviado para prendê-lo, resistiu com "mais vinte homens armados, que disseram não reconhecer a autoridade do juiz e fizeram ameaças" ${ }^{27}$. Embora a documentação não informe sobre a procedência do réu, é possível que não se tratasse de um proprietário abastado, mas de um líder de bando, que para viabilizar seus atos criminosos, valia-se de sua ascendência sobre parcela da população desprovida de posses. À vista de tais fatos, o juiz de paz determinou "a prisão de Jerônimo de Sá e Cunha, e de seus companheiros", o que não parece ter surtido efeito, já que o acusado permaneceu em sua "casa, armado com seus filhos, e alguns estranhos, ameaçando aos vizinhos, tomando despoticamente terrenos alheios [...] e prometendo chumbo grosso a quem se lhe aparecer". ${ }^{58}$

A documentação esgarça ainda as redes de solidariedade entre estes bandoleiros e os potentados locais que os acoitavam em suas propriedades, juntamente com outros criminosos e mesmo quilombolas. É esse o motivo que informa a Representação do Ouvidor Antônio Paulino Limpo de Abreu, acerca da situação reinante no Julgado de São Romão, tradicional reduto

\footnotetext{
${ }^{55}$ ANASTASIA, Carla Maria Junho. A geografia do crime. Violência nas Minas Gerais Setecentistas. Belo Horizonte: Ed. UFMG, 2005, p. 56.

${ }^{56}$ Idem, p. 55.

${ }^{57}$ Arquivo Público Mineiro, Fundo Presidência de Província (PP 1 / 18), cx 152, doc 10. (Uberaba, 8 de abril de 1829).

${ }^{58}$ Idem.
} 
daqueles "malfeitores"59 e onde, segundo o Ouvidor, com "frequência, exatidão, e escândalo, se continua a roubar os Gados, e animais [...] sem que a Justiça os possa [evitar] e mesmo punir, sendo o maior obstáculo o apoio que faz $[\mathrm{em}]$ os proprietários das Fazendas aos mesmos vadios, e ladrões, os quais ainda sendo procurados para serem Capturados, se não consegue porque são avisados [...] chegando a tal extremo, que alguns Proprietários compram dos mesmos Ladrões os Gados que ignoram serem furtados" ${ }^{60}$. Em vista de tais circunstâncias, Limpo de Abreu lembrava que o próprio "Conselheiro Intendente Geral da Polícia em Portaria de 6 de julho de 1824 determinou que os Proprietários de Casas as não alugassem a homens vadios, desconhecidos e sem estabelecimento, e quando o fizessem, ficassem incursos nas penas mencionadas no $\S 8^{\circ}$ do Alvará de 25 de junho de 1760". ${ }^{61}$

Da mesma forma, em sua correspondência ao Presidente da Província, José Luís da Costa Araújo Arcos, juiz de paz do Salgado, comunicava "o roubo de uma escrava e o sequestro de um órfão pelo mesmo homem, um mestiço [...] identificado apenas como Pedro de tal". Para prendê-lo, o dito juiz teria enviado "um oficial com uma portaria sua e outra do Juiz de Órfãos", localizando-se o ladrão "em outro distrito [...] na fazenda de João Cardoso da Silveira, denominada Gameleira". Ao ser preso, contudo, o criminoso fora "resgatado por mais de vinte homens armados, comandados pelo dono da fazenda onde foi encontrado", os quais disseram "que não reconheciam juiz algum e ofenderam as autoridades", atitude perante a qual o referido juiz de paz solicitava que o caso fosse levado ao "conhecimento de S. M. Imperial a fim de que o mesmo Sr. determine o que for servido, porque não havendo exemplo muito principalmente agora no princípio, não farão caso algum dos juízes de paz nestes sertões". ${ }^{62}$

${ }^{59}$ Segundo Anastasia, durante o Setecentos, fez-se particularmente aí temido Belchior Joseph dos Santos, mestiço e matador, expressão do "mandonismo bandoleiro". (ANASTÁSIA, Carla Maria Junho, op. cit., p. 70).

${ }^{60}$ Arquivo Público Mineiro, Fundo Presidência de Província (PP 1/18), cx 328, Doc. 42 (S. Romão, 10 de fevereiro de 1826).

${ }^{61}$ Idem.

${ }^{62}$ Arquivo Municipal de Paracatu (MP), PP 1 / 18 cx 152 Doc. 2. (Salgado, 12 de Novembro de 1828). 
A atuação dos "déspotas do sertão" na implantação da ordem constitucional ...

Todavia, é importante salientar que, assim como nem sempre as relações verticais estabelecidas entre estes bandoleiros e potentados foram de cordialidade - pois, afinal, acabavam disputando os mesmos recursos simbólicos e materiais de distinção e poder ${ }^{63}$-, não raras vezes suas redes de influência cooptaram os próprios encarregados de aplicar a justiça. Essa situação revelou-se mais frequente com os juízes de paz e ordinários, cujos representantes acabavam recorrendo à proteção dos chefes locais para viabilizarem sua força moral e integridade física. Em relação ao comportamento destes últimos - eleitos pelas Câmaras Municipais e com alçada sobre as demandas aí acontecidas $^{64}$-, já em 1799 o Ouvidor da Comarca do Rio das Velhas referia-se às constantes queixas dos povos em relação a estas autoridades, "sempre pusilânimes e condescendentes para o oficio de julgar", e que se mantinham nas Câmaras "sujeitos à prepotência dos homens mais abastados, de quem são dependentes, e devedores [...]". ${ }^{65}$

Expressiva do primeiro caso, por sua vez, é a correspondência de Jacinto Manoel Teixeira, juiz de paz suplente de São Domingos do Araxá, ao Presidente da Província, na qual justifica o "ter se intrometido na jurisdição em execução do Juiz de $\mathrm{Paz}$ Desidério Mendes dos Santos [...], por dever patriótico, já que o tal juiz não trabalhava a serviço do povo, tendo inclusive declarado em público "que um pé tinha no despotismo, e outro na constituição"66. Teria afirmado ainda que "nenhum caso fazia da Assembléia Geral" e que a "corporação das câmaras municipais era de ladrões", e que não acreditava em lei alguma". Por fim, "não bastasse tudo isto, nunca providenciou a bem do público, retirando-se antes para se fazerem desordens: e sempre acompanhado de um valentão" da terra, "mandando matar de público [...] e prendendo a outros em prisão pública", por crime nenhum.

\footnotetext{
${ }^{63}$ Analisando a natureza das disputas e o perfil social dos atores que recorriam à justiça, na Comarca do Rio das Mortes, Vellasco que a maioria dos processos e querelas tratam de disputas entre iguais, entre aqueles que se encontram nos mesmos espaços sociais e concorriam entre si, por recursos materiais e simbólicos. (VELLASCO, op. cit., p. 164-179).

${ }^{64}$ Graça Salgado, op. cit., p. 75.

${ }^{65}$ Arquivo Público Mineiro, Seção Colonial, Secretaria de Governo, códice 268, 1799. ${ }^{66}$ Arquivo Público Mineiro, Presidência de Provícia (P 1 / 18), cx 152, Doc. 21. (4 de Outubro de 1831).
} 
A análise empreendida implica pelo menos duas ordens de considerações. Por um lado, tendo em vista a situação peculiar da região paracatuense - da qual faziam parte antigas áreas do "sertão mineiro" - permite-nos matizar argumentos consagrados pela historiografia, que tendem a concordar com a tese de que "as Minas não propiciaram a emergência de figuras clássicas de potentados, como foram, entre outros, os casos do sertão baiano do São Francisco", tendo antes revelado-se como "situação peculiar à zona mineradora" uma "dependência maior da população ante o Estado", não havendo poder que intermediasse esta relação". Assim, argumenta-se, mediante "a fragilidade dos laços paternalistas, que se fizeram fortes em outros pontos da colônia", o Estado fora aí "o Pai-Patrão todo-poderoso, o defensor e o algoz que dispõe livremente da sorte da arraia miúda" 67 , implicando ainda que "os direitos e os deveres teriam de ser regulados por uma 'força coativa', garantida pelo aparelho administrativo estatal, ou seja, pela justiça do Estado". ${ }^{68}$

Ao contrário disso, os exemplos citados desvendam a coexistência e reivindicação de outros códigos e noções de justiça, bem como o potencial coesivo do patrimônio simbólico reivindicado por aqueles "déspotas do sertão", com capacidade de interferirem no delicado equilíbrio social de suas localidades, instabilizando assim a própria arquitetura do conjunto: o Estado nacional em construção.

Por sua vez, a documentação analisada realça a complexidade dos problemas representados pela atuação destes atores da (des)ordem, tendo em vista dois elementos peculiares à natureza dos conflitos políticos esgrimidos na região: o fato de as alianças e conchavos políticos por eles acionados no contexto do constitucionalismo comportarem um movimento vertical, mobilizando as camadas subalternas (escravos, quilombolas, vadios, livres pobres...) -, e de isso se dar em situação de "fronteira aberta", suscitando outra ordem de preocupação aos olhos do governo provincial: o fato de a região gravitar, em grande medida, na órbita dos acontecimentos processados nas

${ }^{67}$ SOUZA, Laura de Mello e. Os desclassificados do ouro. A pobreza mineira no século XVIII. Rio de Janeiro: Edições Graal, 1982, p. 138.

${ }^{68}$ Argumento defendido em recente estudo de Ivan Vellasco, op. cit., p. 194. 
A atuação dos "déspotas do sertão" na implantação da ordem constitucional ...

provincias limitrofes setentrionais, pondo em xeque a eficácia administrativa do poder regional e, em último caso, confirmando as incertezas sobre os rumos da Nação.

Mediante tais considerações, impõe-se qualificar o teor das relações entre ricos proprietários brancos e aqueles segmentos genericamente designados como as "classes infimas"69, bem como assumir a necessidade de se compreender as tensões e conflitos politicos que permearam o processo de construção do Estado e da Nação brasileiros, à luz dos múltiplos centros de poder secundários que aí conviveram, com suas respectivas periferias.

Embora não seja este objeto da presente análise, vale fixar que a alarmante presença de "bandos que vaga[vam] por aqueles Sertões" ${ }^{\prime 0}$ informava os precoces esforços da Coroa em barrar o trânsito de pessoas pelo Caminho Geral do Sertão do São Francisco para a Bahia, evitando os descaminhos do ouro e todo e qualquer comércio, com exceção do gado ${ }^{71}$. Apesar destas providências, contudo, os arraiais do noroeste mineiro preservaram e mesmo intensificaram os vínculos comerciais com as províncias limítrofes de Goiás, Bahia e Pernambuco. Destacavam-se, aqui, os centros urbanos de Januária, Guaicuí e São Romão, que funcionavam como entrepostos comerciais de

\footnotetext{
${ }^{69}$ Numa Carta Missiva dirigida por José Fernandes de Sousa para a Comissão do Ultramar, em 15 de Setembro de 1821, apresentando os vários pontos que havia necessidade de serem discutidos na Assembleia Nacional "para o bem do povo" da província de Minas Gerais, o problema assinalado era referido em termos dos: infinitos vadios, homens brancos, mestiços, pardos, cabras e crioulos forros, que se não sujeitam ao trabalho, dados a horrorosos vícios, cujos fazem por isso mil desordens, furtos e assassínios, tolerando-lhes os Comandantes das Ordenanças quase todos semelhantes desatinos, e mesmo lhes é dificultoso extingui-los, pois sendo perseguidos em um distrito, mudam-se para outro, e não obstante várias ordens superiores respectivas, pouco ou nada se remedia; carecendo, portanto, as mais ativas providências de severa polícia: os quais bem podem servir no Exército e na Marinha". Carta missiva de José Fernandes de Sousa para o presidente da Assembléia Nacional, dirigida à Comissão do Ultramar, apresentando os vários pontos que haja necessidade de serem discutidos para bem do povo daquela Comarca. (Avulsos do Conselho Ultramarino - Minas Gerais, MS 544, CX 188, Rolo 174, Doc 24, Biblioteca Nacional do Rio de Janeiro, Seção de Manuscritos).

70 "Registro de Ofícios do Governo Provisório ao Ministério", de 2 de maio de 1823. In: Arquivo Público Mineiro, Seção Provincial, (SP 07), p. 150v.

${ }^{71}$ BOXER, Carl R. Boxer. A Idade de Ouro do Brasil (dores de crescimento de uma sociedade colonial). São Paulo: Cia Ed. Nacional, 1969, p. 52.
} 
bovinos e algodão, principalmente, das grandes áreas situadas de ambos os lados do São Francisco. ${ }^{72}$

Tal contexto viabilizou a expansão dos territórios de mandos de potentados locais, frequentemente patronos de bandos armados, conforme referido, perpetrando roubos e assassinatos pelos rudes caminhos dos sertões. No contexto do constitucionalismo, as demandas desses grupos se politizam, mesclando-se com os conflitos verificados nas províncias setentrionais. Conforme alertava o Marechal de Campo Governador das Armas de Minas Gerais ao Governo provisório, em 1823, havia o risco de contaminação dos "Distritos limítrofes das Províncias da Bahia e Pernambuco" com as ideias consideradas subversivas, que agitavam o jogo político nas referidas províncias, mediante os quais recomendava observar-se "os indivíduos que se acolhem a esta Provincia" mineira. ${ }^{73}$

A preocupação das autoridades provinciais com a presença de "desertores" da causa do Brasil, infiltrados no território mineiro principalmente via São Romão e outros Julgados situados ao norte da região paracatuense, reforça a necessidade de se buscar os aspectos tangiveis das rivalidades aí externadas num contexto que extrapola a espacialidade mineira, articulando-se, especificamente, ao perfil das lutas políticas travadas no Alto Sertão baiano. Marcadas pelas "investidas crescentes e audazes dos Mucunãs" ${ }^{74}$ - como eram designados os grupos de homens livres pobres que vagavam pelo sertão baiano perpetrando roubos e crimes -, estas rivalidades mesclavam aspectos de crise econômica, marginalização social, resistência ao recrutamento, embates políticos entre portugueses e homens da terra e insubordinação militar.

\footnotetext{
${ }_{72}$ PAIVA, Clotilde Andrade. População e Economia nas Minas Gerais do Século XIX. São Paulo: USP, Depto de História, 1996, p. 123. (Tese de doutoramento).

73 "Registro de Ofícios do Governo Provisório ao Ministério", de 2 de maio de 1823. in: Arquivo Público Mineiro, Seção Provincial, (SP 07), p. 150v.

${ }^{74}$ Segundo Argemiro, um dos habitantes mais famosos do arraial de Furnas, no termo de Rio de Contas que, ao lado dos homens da terra comprometera-se, desde 1822, com as convulsões políticas no Alto Sertão, fora João Ferreira Mucunã. (SOUZA FILHO, op. cit., p. 181-182.
} 
A atuação dos "déspotas do sertão" na implantação da ordem constitucional ...

Perseguidos, estes "fascinorosos e salteadores"75, como eram descritos pelas autoridades, alastraram-se pelo sertão, infiltrando-se no território mineiro, onde iriam mesclar-se à ação de outros grupos sociais marginalizados, não deixando de ser acoitados e ter suas ações igualmente instrumentalizadas por fazendeiros locais ${ }^{76}$, propagando "doutrinas revolucionárias"77 e insuflando as rivalidades entre "brasileiros"e "europeus"78, bem como o desrespeito às autoridades locais ${ }^{79}$.

A situação se perpetuou durante todo o Primeiro Reinado, agravando-se no contexto da Confederação do Equador, quando diversos Oficios remetidos pela Câmara paracatuense ${ }^{80}$ e o então Ouvidor Limpo de Abreu ${ }^{81}$ ao Governo Provisório informavam sobre "a entrada disfarçada de emissários de Pernambuco", pelos Julgados que estavam em contigüidade com aquela Província, havendo mesmo informações sobre a prisão, em São Romão, de "várias pessoas compreendidas na infame revolução do Ceará". ${ }^{82}$

Em outra correspondência, emitida pelo mesmo Ouvidor, informava-se que "a seca na Bahia" - entendida como "sinal visível" da divina desaprovação, em virtude da "continuada repetição de seus desvairios" - teria "obrigado mais de 3 mil pessoas [...] a abandonar suas herdades e a refugiar-se da fome e da sede nas férteis margens do rio de S. Francisco", onde, "apesar da hospitalidade, cometeram [...] no caminho vários excessos, e desordens", constando que "o Capitão-Mor da Vila do Rio Grande pedira auxílio militar ao Presidente da Província para contê-los e reprimi-los". ${ }^{83}$

${ }^{75}$ Arquivo Público Mineiro, Presidência de Província (P1/30), Cx 2, "Ofícios de SMI ao governador das Armas da Província".

${ }^{76}$ Arquivo Público Mineiro, Câmara Municipal de Paracatu (CMP 11), p. 171-172v.

${ }^{77}$ Ibidem, pp. 64-64v.

${ }^{78}$ Ibidem, pp. 89-89v

${ }^{79}$ Ibidem, pp. 170-171.

${ }^{80}$ Arquivo Público Mineiro, Câmara Municipal de Paracatu (CMP 11), p. 49v (14/07/1824) e p. 11, (01/abril/1825).

${ }^{81}$ Arquivo Público Mineiro, Presidência de Província (P 1 / 18), cx 328, Doc. 4 (14 de Julho de 1824).

${ }^{82}$ Arquivo Público Mineiro, Câmara Municipal de Paracatu (CMP 11), p. 11.

${ }^{83}$ Arquivo Público Mineiro, Presidência de Província (P 1/18) cx 328, doc. 49. (24 de Abril de 1826). O caso não se esgotava à região paracatuense. Também nos arraiais e distritos per- 
Por fim, vale mencionar que a condição fronteiriça da região propiciava, ainda, a impunidade dos crimes, pois, conforme referido pelo juiz de paz de Japoré, Termo da Vila de Salgado, era "hábito cometerem crimes em uma margem do S. Francisco e fugirem para outra, cruzando o rio quando bem entendem" ${ }^{44}$. Tudo isso, adensado pela não rara presença de quilombos e tribos de índios selvagens, servindo de abrigo a criminosos. ${ }^{85}$

Considerada à luz destas tensões de diferentes matizes, a situação interna das Minas Gerais desmente aquela imagem registrada em várias passagens dos Diários do Conselho Geral da Província e do jornal de tendência liberal-moderada O Universal, segundo a qual, cada vez mais consolidava-se o sistema Monárquico Constitucional Representativo na província - mediante o "respeito e entusiasmo pelas leis, constituição, instituições e autoridades constituídas" 86 -, onde o "espírito público" estaria em "marcha que não retrógrada" ${ }^{87}$. Primeiramente, porque não eram claros e tampouco uniformes os sentidos emprestados ao constitucionalismo; em segundo lugar, porque a "modernidade política" em construção não foi um processo linear, comportando avanços e retrocessos, bem como incorporando-se sob

tencentes ao Termo de Minas Novas, ao norte da província, a influência do movimento político das províncias setentrionais se fez notar, dado encontrarem-se estes próximos à Vila de Cachoeira, onde, na conjuntura de 1821-1822, instalara-se um Governo Interino composto por autoridades interioranas, visando consolidar um novo centro de poder constitucional, em adesão ao novo sistema Constitucional e a D. Pedro, preenchendo assim "um vazio de poder proporcionado pela junta da capital e pelo governador das armas que se instalaram sem qualquer contato com o interior". A este respeito, ver o Ofício do ouvidor interino da Comarca do Serro, João Procópio Lopes Monteiro, enviado à Presidência da Província, em 25 de março de 1829 (Arquivo Público Mineiro, Presidência de Província (P1/18), cx 336, Doc. 30).

${ }^{84}$ Arquivo Público Mineiro, Presidência de Província, (P1/18), cx 152, Doc. 7. (14 de Fevereiro de 1829).

${ }^{85}$ No Ofício supracitado, o juiz de paz pedia "apoio para liquidar uma tribo indígena da Missão de S. João de Itacarambi, conhecidos pela sua selvageria e que tentam tomar as terras vizinhas; além disso, aos habitantes da aldeia "publicamente disseram [...] que nada lhes importa juiz de paz e comandante do distrito porque a eles ninguém manda, a pessoa alguma devem obedecer, senão ao capitão Chrispim (que é um índio velho)". Acusava dar providências a respeito, certificando-se de "que é a tal aldeia [...] um couto de preguiçosos, ladrões, vadios e criminosos muito bom." (idem).

${ }^{86}$ Diários do Conselho Gerald a Província de Minas Gerais, Sessão de 18 de dezembro de 1830, p. 50-51; In: APM, microfilme sob referência: rolo 20, gaveta G7, Flash 8, 9 e 10.

${ }^{87}$ O Universal, n. 500, 01/10/1830. (Biblioteca Nacional, Seção de Obras Raras, Microfilme PR-SOR - 766 (1-8). 
diferentes ritmos e tempos; por último, porque nem mesmo entre as camadas dominantes da província havia pleno consenso acerca dos rumos políticos da Nação.

Resumo: Este artigo busca mapear a natureza das tensões que envolveram os potentados do sertão mineiro, no momento da implementação do constitucionalismo na província. Portadores de recursos simbólicos e materiais e por temerem perder suas posições de mando e distinção social, estes homens resistiram aos enquadramentos institucionais em curso, resistindo ao processo de normatização da vida e instabilizando a já precária ordem vigente.

Palavras-chave: Minas Gerais. Constitucionalismo. Justiça. Potentados.

Abstract: This article seeks to map the nature of the tensions surrounding the potentates of the hinterlands of the State of Minas Gerais, Brazil, at the time of implementation of constitutionalism in the province. Bearers of symbolic and material resources and fearing the loss of their positions of power and social distinction, these men have resisted the arrival of new institutional frameworks, opposing the process of normalization of life and destabilizing the already precarious standing order.

Keywords: Minas Gerais. Constitutionalism. Justice. Potentates.

Artigo recebido em 19/11/2011

Artigo aprovado para publicação em 28/06/2012 